\title{
DESAIN SARANA BAWA DAN PENYIMPANAN PERALATAN PRAKTIKUM PRIBADI BAGI PELAJAR SMK FARMASI
}

\author{
Damayanti \\ Mahasiswa Program Studi Desain Produk, Jurusan Desain \\ Politeknik Negeri Samarinda \\ Dita Andansari \\ Staf Pengajar Program Studi Desain Produk, Jurusan Desain \\ Politeknik Negeri Samarinda \\ Email: ditaandansari@yahoo.com
}

\begin{abstract}
ABSTRAK
SMK Farmasi memiliki mata pelajaran yang mengharuskan pelajar melaksanakan praktikum di labolatorium. Kegiatan praktikum mengharuskan pelajar untuk memiliki peralatan pribadi yang wajib dibawa. Saat ini sebagai sarana bawa dan penyimpanannya, pelajar SMK Farmasi menggunakan kotak berbahan plastik yang biasa digunakan untuk tempat makanan. Hal inilah yang melatarbelakangi munculnya ide rancangan ini. Serta permasalahan yang ada saat ini adalah saat jadwal praktikum berlangsung, pelajar SMK Farmasi banyak membawa peralatan, diantaranya peralatan yang mudah pecah maupun yang tidak mudah pecah, namun belum adanya sarana bawa khusus untuk peralatan tersebut. Adapun tujuan rancangan ini adalah untuk mendesain sebuah sarana bawa yang dapat melindungi peralatan-peralatan yang dibawa, diantara lain; pipet tetes, cawan porselin, kaca arloji, batang pengaduk, tissue, lap, sendok tanduk, gunting, kayu penjepit, spatula, forcep, sikat tabung, etiket, label ni, zak plastik, dan botol kaca. Dengan metode perancangan yang sudah dilakukan diantaranya; pengumpulan data analisis, alternatif desain, pengembangan desain dari alternatif terpilih, serta desain akhir. Sehingga dihasilkan desain sarana bawa dan penyimpanan peralatan praktikum bagi Pelajar SMK Farmasi Samarinda yang memiliki sekat-sekat khusus peralatan praktikum pribadi Pelajar SMK Farmasi Samarinda, dan menggunakan gaya desain modern, serta sistem bukaan menggunakan resleting, dengan warna biru dan putih yang melambangkan ciri SMK Farmasi.
\end{abstract}

Kata Kunci : Desain Sarana Bawa, SMK Farmasi Samarinda, Perlatan Praktikum 
Damayanti, Dita Andansari, Desain Sarana Dan Bawa Penyimpanan Peralatan Praktikum Pribadi Bagi Pelajar SMK Farmasi

\section{ABSTRACT}

Pharmacy Vocational Schools have subjects that require students to carry out practical work in laboratories. Practical activities require students to have personal equipment that must be carried. Currently as a means of carrying and storing it, students of Pharmacy Vocational Schools use plastic boxes that are used for food. This is the background of the emergence of this design idea. As well as the problems that exist today are when the practicum schedule takes place, many Pharmacy Vocational students carry equipment, including fragile and non-fragile equipment, but there is no special means of carrying it for the equipment. The purpose of this design is to design a vehicle that can protect the equipment carried, among others; drop pipette, porcelain cup, watch glass, stirring rod, tissue, cloth, horn spoon, scissors, wooden tongs, spatulas, forceps, tube brushes, etiquette, labels, plastic bags, and glass bottles. With the design method that has been carried out including; analysis of data collection, alternative design, design development of selected alternatives, and final design. So that the design of the carrying facilities and storage of practicum equipment for Samarinda Pharmacy Vocational School students who have special barriers to the personal practicum equipment of Samarinda Pharmacy Vocational School students, and using a modern design style, and openings system using zippers, blue and white symbolize the characteristics of Pharmacy Vocational Schools.

Keywords: Carrying Facilities Design, Samarinda Pharmacy Vocational School, Practical Equipment

\section{Pendahuluan}

Menurut Rustaman dalam Agusnar (2016) praktikum merupakan salah satu metode yang ditetapkan dalam pembelajaran guna mencapai tujuan-tujuan pendidikan. Praktikum telah menjadi komponen pembelajaran secara formal. "Praktikum mampu meningkatkan motivasi belajar, mengembangkan keterampilan-keterampilan dasar dalam eksperimen, dan menjadi wahana belajar pendekatan ilmiah serta menunjang pemahaman materi pelajaran".

Berdasarkan wawancara terhadap laboran di SMK Farmasi Samarinda, metode praktikum diterapkan sebagai salah satu dalam kegiatan pembelajaran. SMK Farmasi memiliki mata pelajaran yang mengharuskan pelajar melaksanakan praktikum dilabolatorium. Kegiatan praktikum tersebut mengharuskan setiap pelajar untuk memiliki peralatan pribadi yang wajib dibawa saat melaksanakan kegiatan. Saat ini sebagai sarana bawa dan penyimpanannya, pelajar SMK Farmasi menggunakan kotak berbahan plastik yang biasa digunakan

untuk tempat makanan. Penggunaan kotak berbahan plastik sebagai sarana bawa dan penyimpanan menyulitkan pengguna dalam membawa serta meletakkan peralatan secara teratur. Peletakkan peralatan yang tidak teratur dapat meningkatkan resiko rusaknya peralatan. Selain itu, kotak plastik yang memang tidak dirancang sebagai sarana bawa peralatan praktikum ini kurang ergonomis dan estetis. (Eka dan Firda, 2017)

Dalam perkembangannya untuk menunjang kegiatan praktikum SMK Farmasi membuat dan memasarkan KIT peralatan praktikum farmasi. Produk sarana bawa dan penyimpanan tersebut berupa kotak berbahan plastik. Kotak peralatan praktikum dipasaran berupa kotak plastik dalam ukuran kecil dan berbahan keras. 
Vol. 6, No. 2, April 2019

II. Metode Perancang

Metode perancangan produk oleh Vinod Goel (1995) merumuskan ada 3 tahapan perancangan yakni:

\section{Preliminary Design}

Pengumpulan data dari informasi, analisis data berdasarkan konsep desain makro yang meliputi analisis konsep (konsep fungsi, konsep pemakaian, pemakaian pasar, dan konsep produk), penyusunan program desain sketsa awal. Bagian di atas terdiri dari: Perumusan Masalah, dan Tinjauan Pustaka

\section{Design Development}

Pada tahap ini dibuat alternative gambar komponen serta rancangan secara wire diagram dengan bentuk sketsa dan 3D (tiga dimensi) dari bagian yang tertera di atas terdiri dari alternative desain, pengembangan desain hingga desain terpilih.

\section{Final Design \& Prototype}

Dibuat gambar-gambar yaitu dengan presentasi 3D dan gambar teknik (gambar-gambar tampak, potongan, gambar detail dan spesifikasi teknik produk) tahapan selanjutnya adalah pembuatan komponen-komponen dilakukan assembling (exploded) atau perakitan sehingga menjadi produk (prototype).

\section{Pembahasan}

\subsection{Analisis Pasar}

Analisis pasar adalah suatu penganalisisan atau penyelenggaran untuk mempelajari berbagai masalah pasar. Analisis pasar akan menyangkut lokasi pasar, luasnya pasar, sifatnya pasar dan karakteristik pasar. Strategi pemasaran merupakan hal yang sangat penting bagi perusahaan dimana strategi pemasaran merupakan suatu cara mencapai tujuan dari sebuah perusahaan.

Dalam melakukan analisis pasar, dilakukan pendekatan-pendekatan untuk menentukan sasaran konsumen. Berikut adalah pendekatan-pendekatan yang dilaku- kan:

Segmentasi geografi merupakan pengelompokan pasar. Dikarenakan produk ini ditujukan khusus pelajar SMK Farmasi, maka segmentasi ini ditujukan untuk seluruh pelajar SMK Farmasi Jurusan Farmasi wilayah Kalimantan Timur di Kota Samarinda.

Segmentasi geografis membagi pasar menjadi unit-unit geografis yang berbeda misalnya wilayah, negara, provinsi, kota dan kepulauan. Untuk produk sarana bawa perlengkapan praktikum farmasi dikhususkan untuk pelajar SMK Farmasi Samarinda, segmentsi geografis yang ditentukan adalah di SMK Farmasi, Samarinda Kalimantan Timur. Hal ini dikarenakan agar Pelajar memiliki sarana bawa khusus untuk membawa peralatan praktikum.

Perancangan sarana bawa perlengkapan praktikum ditujukan untuk Pelajar SMK Farmasi Samarinda, yang mana rata memiliki usia 15-17 th.

Segmentasi perbedaan perilaku yaitu yang pertama pada bagian bawah tas memiliki satu kantong yang dapat menyimpan rain cover yang menggunakan sistem zipper. Perbedaannya ialah pada sarana bawa praktikum biasanya,hanya menggunakan kotak plastik biasa dan hanya memiliki satu wadah untuk menyimpan semua peralatan berbeda dengan rancangan saranan bawa praktikum ini memiliki sekat-sekat khusus untuk setiap peralatan praktikum serta memiliki pelindung khusus peralatan yang mudah pecah karena didesain secara khusus.

\subsection{Studi Aktifitas dan Kebutuhan}

Analisis aktivitas dan kebutuhan dilakukan untuk mengetahui aktivitas yang dilakukan berkaitan dengan produk yang akan dibuat sehingga diperoleh kebutuhan pengguna. Berdasarkan kebutuhan tersebut maka dibuat pemecahan untuk memenuhi kebutuhan yang dapat diaplikasikan pada produk. 
Dari analisis aktivitas dan kebutuhan di atas, maka dapat disimpulkan mengenai komponen-komponen apa saja yang harus ada pada produk. Adapun komponen-komponen tersebut berupa:

- Tersedia tempat untuk melindungi barang yang mudah pecah dari benturan:

- Tempat untuk melindungi pipet tetes dengan ukuran $22 \mathrm{~cm}$ x $3 \mathrm{~cm}$.

- Tempat untuk melindungi kaca arloji dengan ukuran Diameter $8 \mathrm{~cm}$.

- Tempat untuk melindungi cawan penguap dengan ukuranDiameter $7,5 \mathrm{~cm}$.

- Tempat untuk melindungi botol syrup dengan ukuran $8 \mathrm{~cm} \times 11 \mathrm{~cm}$.

- Tempat untuk melindungi batang pengaduk dengan ukuran $22 \mathrm{~cm} \times 3 \mathrm{~cm}$.

- Tempat-tempat khusus barang yang tidak mudah pecah:

- Sekat khusus tissue $8 \times 11 \mathrm{~cm}$.

- Kantong jaring untuk spatula, sendok tanduk, dan forcep $12 \times 6 \mathrm{~cm}$.

- Kantong jaring untuk etiket, kertas perkamen, label NI 16 x $15 \mathrm{~cm}$.

- Kantong jaring untuk gunting $12 \times 6$ $\mathrm{cm}$.

- Kantong jaring untuk zak plastik $16 \mathrm{x}$ $15 \mathrm{~cm}$.

- Kantong jaring untuk penjepit kayu 12 x $6 \mathrm{~cm}$.

- Kantong untuk untuk rain cover dengan ukuran $30 \times 6 \mathrm{~cm}$.

\subsection{Analisis ergonomi dan antropometri}

Analisis ergonomi dilakukan untuk meminimalkan resiko kesehatandan keselamatan kenyamanan dalam produk yang dirancang. Dengan begitu efesien kesehatan, keselamatan, dan kenyamanan dalam melakukan kegiatan menggunakan produk dapat maksimal. Sedangkan analisis antropometri dilakukan guna mendapatkan dimensi ukuran atau ukuran produk yang sesuai dengan tubuh pengguna .

Ergonomi sangat diperlukan untuk membuat produk. Begitu juga dengan produk sarana bawa peralatan. Ergonomi berarti yang berkaitan dengan kegiatan mem- bawa,membuka, dan mengambil peralatan yang disimpan didalam produk. Sasaran penelitian ergonomi adalah Pelajar SMK Farmasi pada saat ingin melaksanakan praktikum, secara singkat dapat dikatakan bahwa ergonomi ialah penyesuaian tugas pekerjaan dengan kondisi tubuh manusia dengan dimensi tubuh agar tidak melelahkan.

Analisis ergonomi dilakukan untuk meminimalkan resiko kesehatan dan keselamatan. Dan juga agar kenyamanan dalam melakukan kegiatan menggunakan produk dapat maksimal,ergonomi sangat diperlukan untuk membuat produk. Aktifitas yang dianalisis membutuhkan fasilitas-fasilitas yang dapat digunakan pada saat menyimpan peralatan praktikum. Berikut penjelasan yang lebih terperinci mengenai antropometri yang digunakan pada produk.

\section{Menentukan tinggi tas}

Dimensi tubuh yang digunakan adalah tinggi bahu pada posisi duduk. Gender yang digunakan adalah pria 5\% agar dapat mengakomodir ukuran pengguna secara universal. Tinggi bahu pada posisi duduk pria $5 \%$ adalah ukuran tinggi tas maksimal $=55,5 \mathrm{~cm}$. Dalam pengertian yang lain, tinggi tas tidak boleh melebihi ukuran tersebut. Pada perancangan ini, tinggi tas yang didesain adalah $25 \mathrm{~cm}$. Tinggi ini menyesuaikan ukuran produk yang ada didalam tas tersebut, yakni tinggi cawan porselin 8 $\mathrm{cm}+$ tinggi kaca arloji $9 \mathrm{~cm}+$ tinggi batang pengaduk $4 \mathrm{~cm}+$ tinggi pipet tetes $4 \mathrm{~cm}$ (lihat hal 46).

\section{Menetukan lebar tas}

Dimensi tubuh yang digunakan tebal telapak tangan (sampai ibu jari). Persentil pria $95 \%$ agar dapat mengakomodir ukuran pengguna secara universal. Persentil pria $95 \%$ adalah ukuran lebar tas minimal $=47 \mathrm{~mm}$. Dalam pengertian lain, lebar tas boleh melebihi ukuran tersebut. Pada perancangan ini, lebar tas yang didesain adalah $80 \mathrm{~mm}$. Lebar ini menyesuaikan lebar produk yang ada didalam tas tersebut, yakni 
Vol. 6, No. 2, April 2019

lebar tissue $8 \mathrm{~cm}$ dan lebar botol obat $8 \mathrm{~cm}$. 3.4.Analisis Sistem

Sistem Bukaan

\section{Menentukan panjang tas}

Dimensi tubuh yang digunakan adalah lebar bahu persentil wanita 5\% agar dapat mengakomodir ukuran pengguna secara universal. Persentil 5\% adalah ukuran untuk panjang tas maksimal $=382 \mathrm{~mm}$. Dalam pengertian yang lain, tinggi tas tidak boleh melebihi ukuran tersebut. Pada perancangan ini, tinggi tas yang didesain adalah $300 \mathrm{~mm}$. Ukuran ini sesuai dengan panjang maksimal produk yang ada didalam tas tersebut, yakni panjang batang pengaduk dan pipet tetes $22 \mathrm{~cm}+$ sekat untuk lap 3 $\mathrm{cm}$.

\section{Menentukan Ukuran Tali Selempang (adjustable)}

Dimensi tubuh yang digunakan adalah tinggi bahu.Gender yang digunakan adalah wanita percentile wanita 5\% x 2 dengan tujuan ukuran yang digunakan dapat mengakomodir ukuran secara universal. Percentile wanita $5 \% \times 2$ adalah ukuran untuk panjang tali tas minimal $=501 \mathrm{~mm} \times 2=$ $1.002 \mathrm{~mm}$. Dalam pengertian lain, panjang tali tas boleh melebihi ukuran tersebut. Pada perancangan ini, tali tas yang didesain adalah $1.025 \mathrm{~mm}$ dan tali tas dapat dipanjang pendekkan (adjustable).

\section{Menentukan Ukuran Handle Genggam}

Dimensi yang digunakan adalah lebar telapak tangan dan diameter genggam. Gender yang digunakan adalah pria 95\%tile untuk dimensi lebar telapak tangan dan wanita $5 \%$ tile untuk diameter genggam maksimal. Hal ini bertujuan agar handle dapat sesuai dengan dimensi tubuh manusia secara universal. Lebar telapak tangan pria $95 \%$ tile $=$ lebar handle maksimal $=8,8 \mathrm{~cm}$. Diameter genggam maksimal wanita $5 \%$ tile $=$ diameter handle maksimal $=4,3 \mathrm{~cm}$.
Analisis sistem perlu dilakukan untuk menentukan sistem yang akan diaplikasikan sesuai dengan produk sarana bawa peralatan praktikum pribadi pelajar Smk Farmasi Samarinda. Setelah dilakukan analisis pada beberapa sistem buka tutup di atas, maka sistem buka tutup yang memungkinkan untuk diaplikasikan pada produk Sarana Bawa Peralatan Praktikum Pribadi Bagi Pelajar SMK Farmasi Samarinda adalah Coil zipper. Coil zipper terpilih karena kelebihannya memiliki tarikan lebih licin dan lancar, mampu mengikuti bagian-bagian yang melengkung dan detil karena sifat yang dimiliki coil zipper itu elastis dan tidak berkarat, serta harga dari coil zipper lebih terjangkau.

\section{Sistem Kuncian}

Setelah dilakukan analisis pada beberapa sistem kuncian, maka sistem kuncian yang memungkinkan untuk diaplikasikan pada produk adalah: Side release buckles dan Metal buckle. Side release buckles terpilih karena kelebihannya yang kuat dalam mengaitkan serta bahan mudah ditemukan. Metal buckle terpilih karena kelebihannya yaitu lebih praktis, serta ketersediaan material dipasar mudah ditemukan.

\section{Sistem Sambungan}

Setelah dilakukan analisis pada beberapa sistem jahitan, maka sistem jahitan yang memungkinkan untuk diaplikasikan pada produk adalah jahitan kunci dan jahitan terikat. Jahitan kunci terpilih karena mengacu kepada kelebihannya, yaitu memberikan kesan yang rapih, kuat, serta mampu menjahit kain yang tebal. Sedangkan pada bagian sisi-sisi kantong ataupun pola, jenis jahitan yang diaplikasikan adalah jenis jahitan terikat karena hasil jahitan jenis ini terlihat rapi. Jenis jahitan terikat dilakukan dengan cara menghubungkan kain penyambung di atas pinggiran kain yang ingin dihubungkan satu sama lain. 
Damayanti, Dita Andansari, Desain Sarana Dan Bawa Penyimpanan Peralatan

Praktikum Pribadi Bagi Pelajar SMK Farmasi

\section{Pengaman dalam}

Berdasarkan analisis yang telah dilakukan, sistem pengaman yang cocok adalah Busa Ati. Busa Ati memiliki tekstur yang padat sehingga kuat untuk digunakan sebagai pengaman luar dibandingkan busa teri, busa lapis, dan busa polyfoam. Pemasangan kain jaring lebih praktis serta kain tersebut mudah didapatkan dan memiliki harga yang terjangkau. Pemasangan karet elastis lebih praktis serta bahan tersebut mudah didapatkan dan memiliki harga yang terjangkau

\section{Pengaman luar}

Berdasarkan analisis yang telah dilakukan, sistem pengaman luar yang cocok adalah Kain parasut. Kain ini dipilih karena waterproof atau tahan terhadap air. Kelebihan kain ini mampu menahan rembesan air, sehingga rembesan tersebut dapat bersih kembali.

\section{Finishing}

Setelah dilakukan analisis pada beberapa sistem finishing, maka sistem finishing yang memungkinkan untuk diaplikasikan pada produk adalah Bordir. Finishng bordir dipilih karena hasilnya yang lebih rapi, awet, serta muda dalam pemasangan.

\subsection{Analisis Material}

Analisis material dilakukan untuk menentukan material yang sesuai untuk diaplikasikan pada produk yang akan dibuat. Kebutuhan produk yang akan dibuat adalah produk harus kuat, mudah dibersihkan, aman bagi peralatan praktikum pribadi, serta memiliki harga yang terjangkau dan mudah ditemukan. Adapun material yang dapat diaplikasikan pada produk ini ialah kain drill , kain dolby, kain kanvas, serta material berbahan plastik.

Ditinjau dari kekuatan materialnya, kain lebih kuat dibandingkan material plastik, bahan kain lebih tahan lama, kain Drill lebih kuat dan tahan lama dibandingkan kain kanvas dan kain Dolby. Sedangkan dari segi harga, plastik memiliki harga termurah, namun pada material kain, kain kanvas lebih memiliki harga terjangkau dibanding kain Drill yang memiliki harga standart dan Dolby yang memiliki harga yang lebih mahal. Dan dari segi tidak mudah lecet, kain Drill lebih tahan cukup tinggi terhadap abrasi, serta goresan sehingga tidak mudah lecet dibandingkan kain Dolby yang permukaannya terkesan glossy dan kain kanvas yang mudah lusuh jika terkena kotor.Material kain lebih tahan lecet dibandingkan plastik yang bisa saja pecah dan tergores.

Dari analisis di atas dipilih kain Drill, material kain dipilih dikarenakan lebih mudah dibawa karena bahannya yang tidak kaku serta memiliki tali selempang yang memudahkan pengguna dalam membawa sarana bawa tersebut. Serta material kain dipilih karena lebih unggul dalam ketahanan, plastik lebih mudah pecah sedangkan kain tidak pecah karena lebih tahan lama, kuat, tidak mudah lecet, harganya yang masih terjangkau serta mudah ditemukan. Keunggulan lain dari kain ialah kain dapat dibentuk sesuai ciri farmasi itu sendiri, contonya dari segi tampak visual. Kain drill difungsikan sebagai material luar tas, dan plastik digunakan sebagai pengaman dalam peralatan praktikum.

\subsection{Analisis Bentuk}

Analisis bentuk diperlukan dalam menentukan bentuk yang sesuai yang akan diterapkan pada produk. Ditinjau dari sasaran penggunauntuk produk ini ialah pelajar SMK Farmasi Samarinda Jurusan Farmasi, maka kesan yang harus ditimbulkan ialah kesan profesional.

Adapun pendekatan bentuk yang digunakan pada produk ini adalah: Gaya desain modern, Klasik, Modern vintage

Dari ketiga gaya desain yang paling mendekati kesan profesional ialah gaya desain modern, sedangkan gaya desain klasik menimbulkan kesan yang klasik atau kuno, serta modern vintage menimbulkan kesan 
Vol. 6, No. 2, April 2019

modern namun memiliki kesan terhadap desain masa lampau.

\subsection{Analisis Warna}

Berikut ini warna-warna yang sering ditemukan dalam bidang kesehatan yaitu: warna merah, putih, biru, dan hijau. Adapun warna yang sering ditemukan dalam bidang farmasi khususnya SMK Farmasi Samarinda ialah warna biru dan putih, sedangkan warna merah sering ditemukan dalam bidang PMR, dan warna hijau sering ditemukan dalam bidang keperawatan.

\subsection{Hasil Desain}

Pada desain awal dalam gambar 1 , tas memiliki 1 bukaan sehingga lebih praktis, dan tempat penyimpanan rain cover tas berada dibagian bawah tas dilengkapi resleting sehingga bagian belakang tas lebih estetik dengan tidak adanya kantong, tempat badge name dan logo tepat berada disisi depan sehingga menimbulkan kesan yang profesional, bentuk yang dimiliki tampil unisex, artinya pelajar laki-laki dan perempuan dapat menggunakannya.

Desain awal dalam gambar 1 tersebut selanjutnya dikembangkan menjadi beberapa alternatif desain yang kemudian dianalisis sesuai spesifikasi desain yang telah ditentukan sehingga terbentuk desain final seperti yang ditunjukkan dalam gambar 2 .

Desain final tersebut selanjutnya dibuat prototipenya untuk bisa dipakai operasional. Selanjutnya dari prototipe ini bisa dibuat acuan untuk proses produksi massal agar bisa diproduksi oleh industry supaya bisa dipasarkan ke konsumen.

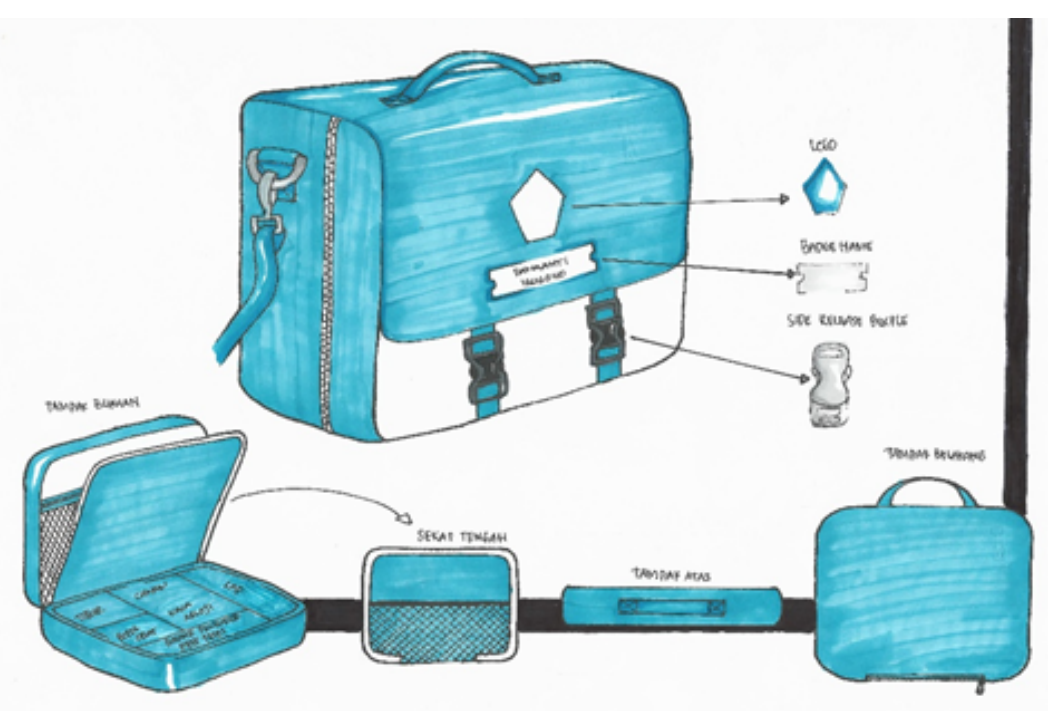

Sumber: Dokumen Pribadi, 2019

Gambar 1. Desain Awal 


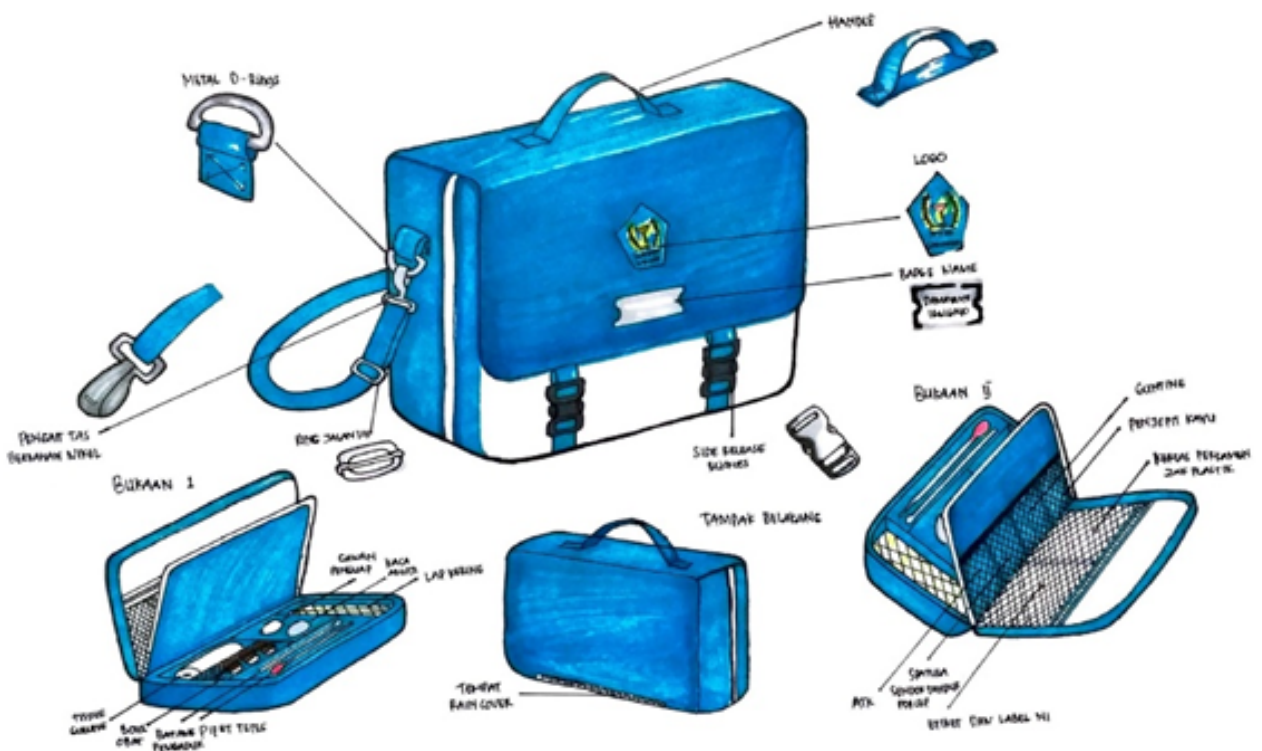

Sumber: Dokumen Pribadi, 2019

Gambar 2. Final Desain

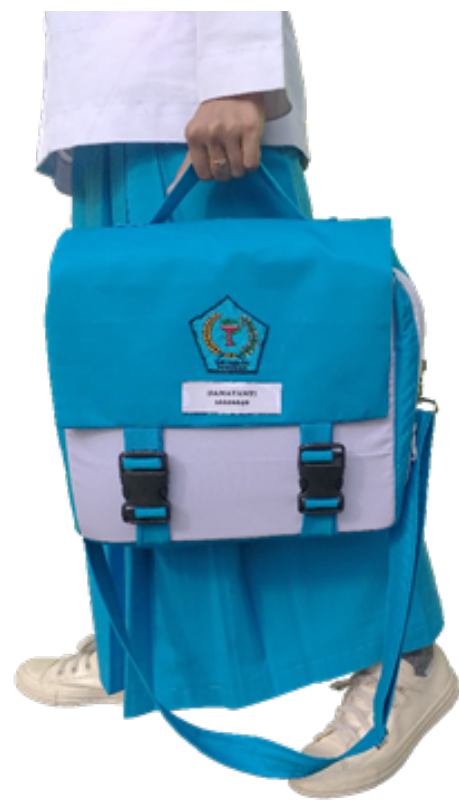

Gambar 3. Prototipe produk

\section{Kesimpulan}

Berdasarkan hasil dari "Desain Sarana Bawa dan Penyimpanan Peralatan Praktikum Pribadi Bagi Pelajar SMK Farmasi Samarinda", dapat disimpulkan

Untuk membawa dan menyimpan peralatan praktikum pribadi dibutuhkan tas khusus sehingga memudahkan Pelajar dalam aktivitas membawa dan menyim74 pan peralatan. Tas khusus untuk peralatan praktikum harus disesuaikan dengan peralatan yang dibawa dan dilengkapi dengan wadah-wadah khusus agar peralatan tersusun rapi dan peralatan tidak mudah rusak. Diperlukan penerapan desain yang sesuai dengan usia dan kebutuhan pengguna. Tas peralatan praktikum pribadi ini dibuat dari bahan yang kuat sehingga mampu digunakan dalam jangka waktu yang panjang dan dilengkapi dengan komponen dan dimensi yang telah disesuaikan dengan pengguna.

Saran yang dapat diberikan adalah sebaiknya Pelajar SMK Farmasi Samarinda memiliki fasilitas khusus untuk peralatan praktikum yang rutin digunakan dalam kegiatan praktikum yang mendukung proses belajar mengajar dan apabila produk yang dirancang akan diproduksi secara massal sebaiknya dilakukan pengembangan, dari material dapat dikembangkan menggunakan material yang mudah dibersihkan serta tahan terhadap air, sehingga produk bisa lebih sesuai dengan apa yang dibutuhkan dan diinginkan pengguna. 
Vol. 6, No. 2, April 2019

\section{Daftar Pustaka}

Arti Warna Biru. 18 April 2019. (https://fitinline.com/article/read/unsur-desain-fashion-unsur-warna-makna-warna-2/).

Arti Warna Putih. 18 April 2019. (https://fitinline.com/article/read/unsur-desain-fashion-unsur-warna-makna-warna-2/).

Cara Jahitan Terikat. 18 April 2019.http://languages.coatsindustrial.comm/id/informstion-hub/apparel-expertise/stitch-types

Cara Jahitan Susun. 18 April 2019. http://fitinline.com/article/read/8-tipe-jahitanm-pada-pakaian-berdasarkan-jumlah-kompnen-yang-digunakan/

Jenis Metal Buckle. 18 April 2019.https://www.aruncraft.com/mengenal-jenis-komponentali-tas-strap-pegangan-handle-tas

Kegunaan Busa Ati. 18 April 2019. https://fitinline.com/article/read/9-jenis-bahan-yang-dapat-digunakan-sebagai-pelapis-tas/

Kegunaan Busa Lapis. 18 April 2019. (https://fitinline.com/article/read/9-jenis-bahan-yang-dapat-digunakan-sebagai-pelapis-tas/).

Kegunaan Busa Teri. 18 April 2019. (https://fitinline.com/article/read/9-jenis-bahan-yang-dapat-digunakan-sebagai-pelapis-tas/).

Kelebihan Coil Zipper. 18 April 2019.https://dwicahaya.co.id/products-category/coi;-zipper/

Pegertian Bordir. 18 April 2019.(https://bordirpro.com/2018/03/20/pengertian-bordir-ini-dia-definisi-yang-harus-anda-mengerti/).

Pengertian Gaya Modern. 18 April 2019. (https://interiorudayana14.wordpress.

com/2014/05/15/konsep-desain-interior-modern/)

Pengertian Invisible Zipper. 18 April 2019. https://fitline.com/article/read/7-jenis-resleting-berdasarkan-bahan-baku-pembuatannya

Pegertian Sablon. 18 April 2019. https://ahlimenyablon.weebly.com/ 